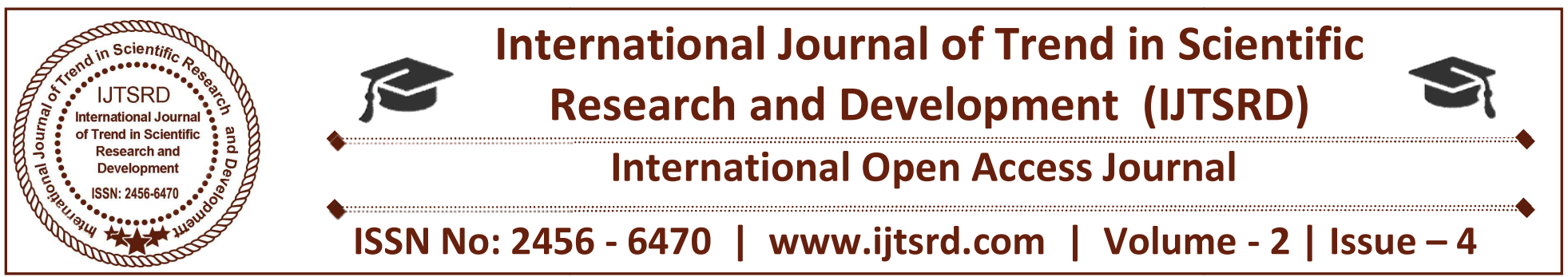

\title{
Children and Legal Literacy
}

\author{
Nazarudeen. E \\ Research Scholar, JJT University, Jhunjunu, Rajasthan, India
}

\section{ABSTRACT}

Functioning of democracy is replenished by the awareness of the people. Legal awareness is equally important as socio cultural awareness. Public legal education saves not only individuals but also society as a whole. Interests of the individuals and communities are to be protected to attain the goal of development. Laws and legal machineries are having a prominent role in this regard. In the present days of welfare legislation the duty of the legislature has widened. They have to make enactment with respect to each and every subject related with human life. But enactment alone is not sufficient. What is enacted should be conveyed to the people for whom it is being enacted. Though our legislative body makes legislations regarding so many subjects connected with our life the knowledge regarding such laws is not conveyed to them. It is a sad situation because there are laws to protect the people but the people do not know that there are laws to save them from difficulties. Population of a country consists of different categories depending on the purpose for which they are categorized. Based on age there are children, youths and aged people. Each of these groups needs special treatment. To protect the interests of child community there are constitutional provisions. There are various Acts intending for their welfare. Multifarious institutions are formed as per the provisions of such welfare legislations for the sake of country's child community. All these legal norms and institutions are having international standard also because many of the related statutes are enacted as per the clarion calls of the United Nations Organizations to its member countries. All such statues and institutions are meant for different phases of child community, such as, education, health, child labour, juvenile delinquency etc. So there are statues to coordinate the education of the children, to control and regulate child labour, to check and control juvenile delinquency and the like. The thing that is to be noted is that in spite of laws related with education many children are illiterate; in spite of laws to control and regulate child labour children are being employed in hazardous work and subjected them to exploitation; in spite of laws to check and control juvenile delinquency the number of juveniles in conflict with law is increasing and in spite of laws to protect children from sexual exploitation many children are being subjected to sexual atrocities. Thus child community is being mentally, physically, emotionally and sexually exploited by the unscrupless people around them. The thing that is to be considered seriously is that lack of awareness of society, in general and children in particular regarding the concerned laws is one among the several reasons responsible for the pathetic condition of the child community of the nation. So legal awareness to the members of the society regarding the provisions contained in the related laws will make them thoughtful about the implications of such laws in the life of each members of the society if they violate it. Thus the fear created through the legal awareness will force them to abstain from the violations of legal provisions. Thus finally it will become their way of life. Hence programmes are to be designed to impart legal awareness to the members of the society.

Legal literacy, sometimes called public legal education, is the empowerment of our people regarding issues involving the law. It helps us to promote consciousness of legal culture, participation in the formation of laws and rule of law which will enhance resources in every human beings. Public legal education sometimes called civics education, 
comprises a range of activities intended to build public awareness and skills related to law and justice system.

Legal literacy, for a country like India gains added significance. To make our system of democracy fruitful and perfect our people must have a public legal education. In the present day circumstance absence of public legal education and legal awareness reflects in one way or other in the lives of our people. Many of our people, either individually or collectively, are being exploited by the unscrupless of our society in many respects. To save each sects of our people from the exploitation of such unscrupless people we have a flood of enactments. Unlike primitive ages modern age is remarkable due to abundance of Laws. Laws are being enacted to maintain law and order in the society and in the absence of which societies will be in topsy, turvey condition. In such a situation the interest of the individuals and societies cannot be protected. Therefore it is the laws and legal machinery which provide facilities for the overall development of individual and society by protecting their interests. In this regard modern governments enact laws touching each and every aspects directly or indirectly related with members of the society. So it is not an exaggeration to say that today there is nothing in the universe which is not touched by law. Consequently in the present day circumstances we are all slaves of different laws. That means laws control us. It controls us from womb to tomb. In the matter legislation the legislatures of modern countries are showing activistic approach. That means they are actively making enactments regarding a wide variety of subjects. India is also not an exception to this.

Prevalence of plenty of laws is the sign of a healthy political order, though there are some inherent draw backs of their own, such as, procedural complexities, waste of money and time and the like. Yet, it is to be born in our mind that law is not an end in itself. Legislation succeeds when it is fruitfully implemented and the victim or aggrieved party gets benefit as envisaged and intended by the legislature. The attainment of this goal of legislation depends upon the awareness of society, in general and individual, in particular regarding concerned legislations. But the most important drawback of our legal system is that the society for whose safety and security enactments have made are not at all aware of such laws. There are different laws to protect the interests of different sections of our community. One such prominent section of our society is children they are the supreme asset of our nation.

As everybody knows children are the weaker section of our society and they are most vulnerable to be exploited physically, mentally and emotionally. Various enactments have been made by our governments to make sure their safety and security, to make sure their comprehensive development and to make sure their future bright.

There are some basic and the relevant enactments made for children. A brief discussion regarding some of them is given below.

\section{Constitution}

Reference of constitutional provision are immensely important in the discussions of any of the laws of our land because constitution is the supreme and any enactment made by the legislature should be subjected to the constitutional provisions.

The provisions relevant to the children contained in parts III, IV \& IV A of our constitution are the following:-

a. Article $21 \mathrm{~A}$ of the constitution provides free and compulsory education to all children between the age of 6 to 14 .

b. Article 24 of the constitution prohibit the employment of children below the age of 14 in factories, mines or any other hazardous employment.

c. Article 23 of the constitution prohibits the abuse of the tender age of children.

d. Article 39-f provides that children are given opportunities and facilities to develop in a healthy manner and in conditions of freedom and dignity and that youth are protected against exploitation and against moral and material abandonment.

e. Article 45 of the constitution directs early childhood care and education for all children until they complete the age of six years.

f. Article 51 A states that providing education to his child or ward between the age of 6 and 14 years is the duty of the parent or guardian. 


\section{Juvenile Justice (Care and Protection of Children) Act, 2015}

The Act justifies the provisions of the India constitution regarding fundamental rights of the children, The Act also support the International Convention on the Rights of the Child, 1992 which was adopted by the General Assembly of the United Nations organization.

According to section 2 (35) "juvenile" means a child below the age of eighteen years. Among the principles given in the Act (S.3) the principles of presumption of innocence and principle of dignity and worth are to be specially made mentioned of. The Act provides for the constitution of a Juvenile Justice Board to regulate those children who are in conflict with law. The Act also provides for the constitution of a Child Welfare Committee to give care and protection to those children who need the same. The provisions of the Act safeguard the best interest of the children and there for it is having sufficient potentialities for the overall development of our children.

\section{Protection of Children From Sexual Offences} Act, 2012

The Act aims at the proper development of the child through protecting their privacy and confidentiality and respect their persons by all means in all stages of Judicial processes involving child and giving paramount importance to the well -being of the child by ensuring the healthy physical, emotional, intellectual and their social development. Detailed provisions have been included in the Act regarding sexual offences against children. Heavy fines and capital punishment have been prescribed for such offences with a view to ensuring a deterrent and preventive effects in the society.

\section{The Commission For The Protection of Child Right Act, 2005}

The Act provides provisions for the constitution of commissions for the protections of child right in the national and state levels. The Act mandates that government should include eminent persons of commitment to child issues. The Act provides for the establishment of children's court to ensure speedy trial of offences against children.

\section{The prohibition of Child Marriage Act 2006}

The Parliament of India enacted the prohibition of child marriage Act, 2006 to give effect to the restrainment of solemnization of child marriage.According to section 2 (a) child means a person who, if a male has not completed 21 years of age, and if a female has not completed 18 years of age. The Act made child marriage to be voidable at the option of contracting party. More over any offences under this Act shall be cognizable and non bailable.

\section{The Child Labour (Prohibition and Regulation) Act 1986}

The Parliament of India enacted the Child Labour Prohibition and Regulation Act 1986 to give effect to the following as envisaged in the objective clause of the Act.

a. Banning the employment of the children in specified occupation and processes

b. Laying down the procedure to decide modifications to the schedule of banned occupation and processes.

c. Regulating the terms and conditions of work of children in employments where they are not prohibited from working.

d. Laying down enhanced penalties for employment of children in violations of the provisions of this Act.

e. Obtaining uniformity in the definition of child in the related works.

\section{The young persons (Harmful Publications) Act 1956}

Parliament of India enacted The Young Persons (Harmful Publications) Act, 1956to prohibit the publication and dissemination of stories of glorification of crimes, violence and vise so as to discourage the anti-social tendencies among children as envisaged in the object clause of the Act. The Act prescribes penalties for sale etc. of harmful publications and prescribe punishment for those who violate the provisions of the Act.

\section{The Kerala Borstal Schools Act 1961}

The preamble of the Kerala Borstal School Act 1961 is enacted to make provisions for the establishment 
and regulation of Borstal schools in the state of Kerala for the detentions and training of adolescent offenders. The Act empowers the court to pass orders of detention of adolescent offender in borstal school in appropriate cases and also there are provisions for the transfer of incorrigibles to prisons.

\section{The prevention of juvenile smoking Act}

An Act to provide for the prevention of juvenile smoking. Passed by His Highness on the $16^{\text {th }}$ day of Kanni 1096, corresponding to the $1^{\text {st }}$ day of October 1920.

The Act made provisions for imposing penalty on selling tobacco to youthful persons. When an offender is produced before a magistrate he may be either discharged with a warning or inflict a fine on him. Any sentence of wiping passed under this Act shall be administrated in the presence of the magistrate.

\section{The children (Pledging of Labour) Act, 1933}

The children (pledging of Labour) Act, 1933 is enacted to prohibit the making of agreements to pledge the labour of children and the employment of those children whose labour is pledged. The Act expressly declared that an agreement to pledge the labour of a child is void. Penalty has been prescribed by the Act for making agreement to pledge the labour of a child with the parent or guardian and also for employing a child whose labour has been pledged.

From the brief discussion given above, $t$ can be seen that our legislature is very keen in addressing issues related with our child community. A considerable number of legislations have been made by the legislature of India touching almost all aspects of the life of the children.

To make our child community legally literate the following methods can be used:

1. Include basic and relevant law in the school and college curriculum

2. Conduct periodical workshops and seminars regarding basic and relevant laws in school and college campuses.

3. Conduct debate and discussions regarding contemporary legal issues in schools and college campuses and ensure active participation of the students both in the dice and stage along with eminent luminaries.
4. Allow grace mark in getting admissions to higher course to those students who show outstanding performance in above mentioned legal programmes as a source of inspiration.

From the illustration so far made it is clear that we have laws with sufficient potentialities to protect our child community. But even in the midst of these powerful laws the child sect of our society lives in a state of lawlessness. Many of them are being deprived of their fundamental rights and many of them are not getting the protection envisaged in the above mentioned laws. It is so because our society in general and child community in particular are not aware of the protection guaranteed by the laws enacted for them. More over the cases registered against the children are also increasing though there is a slight fluctuation in the number cases registered. As per the crime statistics published by the National Records Bureau, under the ministry of Home Affairs, Government of India 2015 the number of cases registered against juveniles in conflict with law in the year 2005 was 18939. The crime statistics also shows that the number of cases registered against them have been increasing in the subsequent years except 2009, 2010 and 2014. In 2015 the number of cases registered against them is 31396 . The experiences show that in the most majority of cases the juveniles are not at all aware of the legal consequences of the crime committed by them. The important aspect in this regard is though our laws are having the effect of "constructive notice" the knowledge or awareness regarding the concerned laws are not reaching to those for whom they have been enacted. Through imparting knowledge and awareness regarding concerned laws to the members of the society two important advantage can be obtained. They are the following.

a) Since the members of the society as a whole is made aware of the concerned laws it will have deterrent effect in them in committing offence against anybody, particularly children.

b) Since the child community as a whole is made aware of the relevant and concerned laws it will have a preventive effect in them in committing any offences against anybody.

So the need of the hour is to make them literate of these laws so as to prepare them to set the law enforcing machinery in motion which is in a state slumber of and on, when the criminals target them. It will make a deterrent effect in the society and it also 
International Journal of Trend in Scientific Research and Development (IJTSRD) ISSN: 2456-6470

prevent our children from committing crimes. The deterrent and preventing effects of legal literacy among children will create a new culture in them namely culture of peace and non-violence.

\section{REFERENCES}

1. George Johnson and Dominic Johnson. Juvanile Justice \& Child Rights Laws 2016

2. P.P. Rao "Universal Human Rights and Fundamental Rights in India". IJIL Vol.45

3. Crime in India 2015, National Crime Records Bureau .
4. Dr. K.N. Chandrasekharan Pillai : R.V. Kelkar's Criminal Procedure Third Edition Reprinted 2011

5. P.S. Atchuthen Pillai : Juris Prudence and Legal Theory Third Edition Reprinted 2005

6. M.R. Mallick : Criminal Manual 2015

7. J. N. Pandey 2003 Constitutional Law of India

8. Martin H Neumeyer1949 Juvenile Delinquency in modern society.

9. George Johnson and Dominic Johnson 2016 Juvenile Justice and Child Rights Laws.

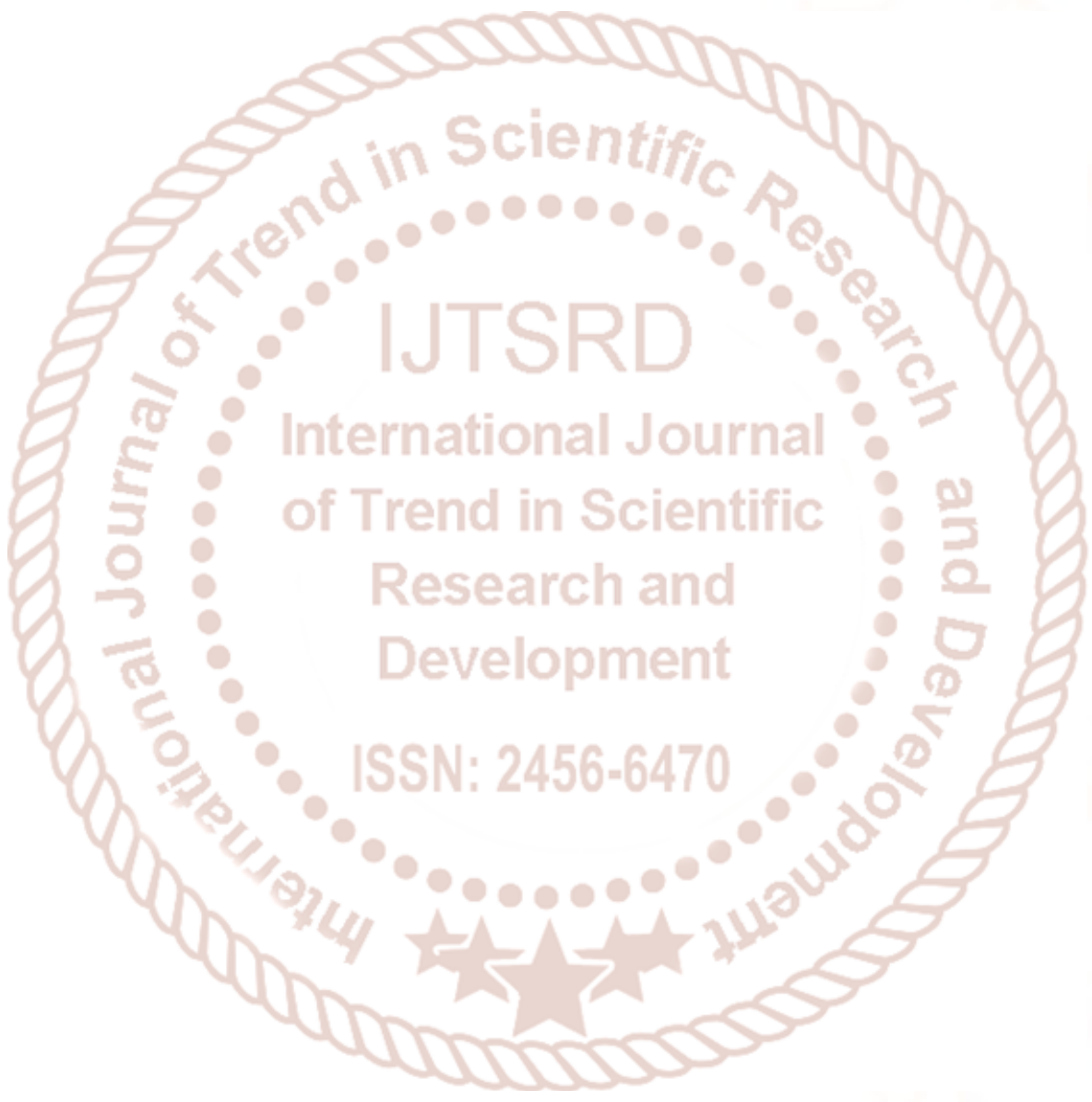

